\title{
Applying the competence-based approach to management in the aerospace industry
}

\author{
Mariam Arpentieva ${ }^{1, *}$, Olga Duvalina $^{1}$, Svetlana Braitseva $^{1}$, Irina Gorelova $^{2}$, and Anna \\ Rozhnova $^{2}$ \\ ${ }^{1}$ Tsiolkovskiy Kaluga State University, Psychology Department, 248023 Kaluga, Russia \\ ${ }^{2}$ Russian Academy of national economy and public administration under the President of the Russian \\ Federation, Volgograd Institute of management, 400131 Volgograd, Russia
}

\begin{abstract}
Problems of management in aerospace manufacturing are similar to those we observe in other sectors, the main of which is the flattening of strategic management. The main reason lies in the attitude towards human resource of the organization. In the aerospace industry employs 250 thousand people, who need individual approach. The individual approach can offer competence-based approach to management. The purpose of the study is proof of the benefits of the competency approach to human resource management in context strategic management of the aerospace organization. To achieve this goal it is possible to obtain the method of comparative analysis. The article compares two approaches to personnel management. The transition to competence-based human resource management means (a) a different understanding of the object of management; (b) involvement in all functions of human resource management «knowledge - skills - abilities» of the employee; (c) to change the approach to strategic management aerospace industry.
\end{abstract}

\section{Introduction}

The aerospace industry is one of the few that makes the Russian economy more competitive. A particularly important issue in the field of aerospace engineering is the question of the object of the management. The object of knowledge is a process, phenomenon, originating in scientific reflection in connection with their problematic situation. The number of such objects make management very difficult and un-successes. Un-differences make expert's and manager's positions ambiguous interpretation A priori, in the theory of strategic management, an organization was supposed to be an object, introducing strategic management into practice. Despite this, reality showed that, depending on the point of view on the essence of the organization, different management concepts was being form. This ambiguity led to the conclusion that «the heterogeneity of units of analysis» [6]. In the theory of strategic management is justified a two-level interpretation of the units of analysis, the object of strategic management. First, it is macro-object, it is organization. Secondly, it is a source of competitive advantage of the enterprise (microobject). With the interpretation of competitive advantage, is not so simple. In the process of

\footnotetext{
*Corresponding author: mariam rav@mail.ru
} 
interpreting the notion of "competitive advantages", a much greater ambiguity is revealed. In fact, the evolution of the theory of strategic management is the evolution of the filling of the term "competitive advantages". The availability of physical resources has levelled out the possibility of obtaining a sustainable competitive advantage from the outside. What is inside the enterprise itself can be called a competitive advantage - the issue is much more complicated. Scientists are still arguing about him. But if we analyse the known approaches, the solution of this question is reduced in all the ways to the concept of "competence" [8].

\section{Materials and Methods}

The primary method is comparative analysis. Of particular interest is the benefits of implementing a competency approach to personnel management. Discusses various approaches to the desired concept are shown prospects for management based on the competence approach. The context of research is the strategic management in modern conditions. The strategic management theory sees the source of competitive advantage in dynamic abilities. Under the dynamic abilities of many researchers understand exactly competence. Researchers interpret the term «competence» in different ways [9].

\section{Results}

The transition to management based competency approach helps us: 1. diagnose the human resources of the organization (competence are the basis of the evaluation criteria resource); 2. to form a «competence passport» of employees and departments (this document helps to manage lifecycle of an employee); 3. to determine the place and role of each employee in implementation of the strategy of the organization; 4. identify priority areas of personnel policy; 5. to revise the emphasis in the incentive system in the enterprise; 6 . determine the need and direction of training (retraining) of employees. This complex helps us in the implementation of strategic objectives.

\section{Discussion}

The etymology of the term «competence» comes from the Latin «competentia» as the membership rights. Used in the French language since the late XVIII century in the meaning of authority as confirmed right, authority. In the mid of the XIX century began to was use to denote a range of issues, in which anyone versed professional, with knowledge of the matter. The first part of the word (prefix com-) suggests that competence, as the authority must be confirm by something (a law, administrative act, power of attorney). The second part of the word (root base petere-) suggests, that competence as the authority may not appear effortless, it must be achieved, «summon». In the West, the revival of this notion an introduction it to the language theory (N. Chomsky, R. White) led to the transition to competence based education in the mid of the XIX century [7]. Further, the scientific community began work to identify the components of competence. A pioneer in this field was J. Raven. He identified 39 types of competences that equates with the «motivated abilities», a special place is given to self-education and self-development. In the modern management competence primarily defined as a «combination of knowledge, skills, motivational factors, personality traits, and situational intentions, which provides the effective solution of a task by a certain class in a certain organization at a certain place in a certain group» [10]. Thus, "competency» is inseparable from the personality, whereas «competence» - characteristics of the workplace or the working task. It should be 
remembered that (1) competence is a quality or property pertaining to professional activities. Competence can be consciously changed (2). That is why competence can be called dynamic, changing abilities. They can be transformed into specific needs of strategic management. In all situations and periods, the concept of "competence" is used by the Labor Code of the Russian Federation in the context of the notion of the powers of management bodies. Thus, the interpretation of the term in labor relations has not changed since the beginning of the XX century. The dictionary of foreign words issued at that time gives the definition of competence as the terms of reference of an institution or person. Modern Russian system of education is actively implementing a competence-based approach. In the education system under the purview understand the components of the work function in terms of «knowledge - abilities - skills». Professional dictionary is missing. The system of professional standards are not yet ready to answer the queries no education system, no system of labour relations. This state of things J. Baudrillard called simulation. [1] Simulation of a competence campaign in all spheres of life leads to tragic results (Figure 1).

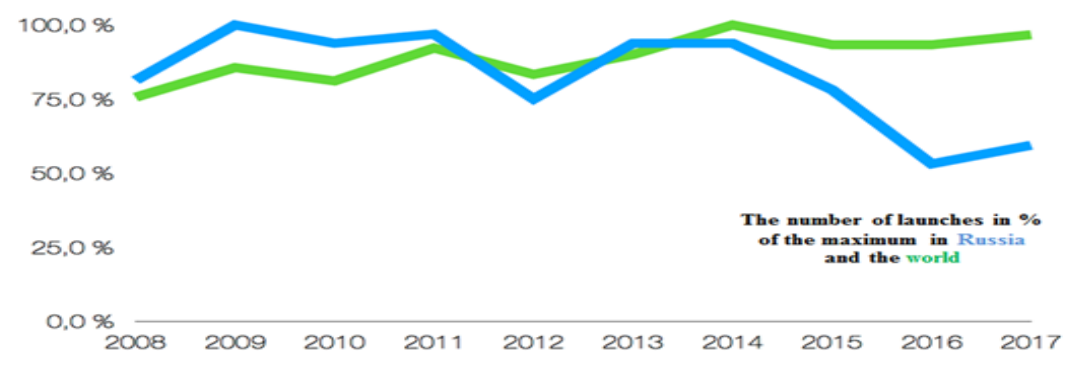

Fig. 1 Dynamics of space launches in Russia and in the world in 10 years [11].

The simulation results prove the use of competence approach in management (table 1). For implementing of competency in management, this term is required relevant interpretation of the object of management [2]. It involves the allocation of competences as micro-object in the management object. Macro-object stands the man himself. This understanding is reflected in the concept of human resource management, respectively, while all management functions associated with the development of the management object. We can distinguish a number of functions: 1. Recruitment. The search for a suitable candidate for a position is done by declaring the required competencies «knowledge abilities - skills» which is included in the strategic management process and goal setting. This approach determines the versions of the methods of recruitment and given the reputational risk of the organization. 2. Selection of personnel is carried out as the process of identification of clearly defined requirements for the post and competence of the candidate. Hence, practitioners and theorists also have a choice of criteria and methods of selection. 3. Regulation of labor relations involves paperwork, which includes the future development of the employee (including in the reserve, career profile, reward system, involvement in voluntary insurance, etc.). The issue of compliance of labor legislation is not necessary. 4. Certification of personnel is carried out exclusively to identify the strategic potential of the organization. 5. Staff training is carry out based on the needs of the organization to achieve strategic objectives. The variability of the external environment suggests new requirements to human resources, determines the need of new competences. Hence, practitioners and theorists have ideas about the framework for the development of training programs, programs for individual development. From the idea of goals there is an understanding of the need to spend money on this aspect of management. 6. Motivation and stimulation of the personnel is form based on strategic needs and opportunities of the 
organization. The creation was motivate by the need for competence is stimulated by the degree of its involvement in the strategic process. 7. Downsizing of staff is in accordance with the strategic needs of the resource of the enterprise.

Table 1. Results of the compensation approach: simulation and implementation.

\begin{tabular}{|c|c|c|}
\hline Simulation & $\begin{array}{l}\text { Competence-based } \\
\text { approach }\end{array}$ & Implementation \\
\hline $\begin{array}{l}\text { The enforcement of the decision. } \\
\text { The principle of operation in the } \\
\text { organization: «There are two } \\
\text { opinions regarding the solution to } \\
\text { the problem. One solution belongs } \\
\text { to guide other a priori wrong» }\end{array}$ & $\begin{array}{c}\text { Tool to reach } \\
\text { consensus/consent }\end{array}$ & $\begin{array}{l}\text { In the strategic management means } \\
\text { understanding the alignment of } \\
\text { interests }\end{array}$ \\
\hline $\begin{array}{l}\text { The prevailing mechanism of self- } \\
\text { affirmation, which eliminates the } \\
\text { possibility of recognizing user } \\
\text { errors }\end{array}$ & $\begin{array}{l}\text { Objective function: } \\
\text { strategic management } \\
\text { the essence of setting a } \\
\text { goal and achieving it }\end{array}$ & $\begin{array}{l}\text { Development of goals, mission, } \\
\text { vision control system, staged its } \\
\text { achievement, taking into account } \\
\text { permanent error analysis }\end{array}$ \\
\hline $\begin{array}{l}\text { Management in the academic } \\
\text { sense is missing. Replace his } \\
\text { powers, disappears the subject - } \\
\text { object relationship Failures justify } \\
\text { human factor and national model. }\end{array}$ & Management tools & $\begin{array}{l}\text { Rational mechanisms and } \\
\text { procedures which are implemented } \\
\text { subject - object relationship }\end{array}$ \\
\hline $\begin{array}{l}\text { Subjective and irrational, imposed, } \\
\text { external environment conserved } \\
\text { its manifestations are spontaneous, } \\
\text { unpredictable, depend on the } \\
\text { personality }\end{array}$ & $\begin{array}{l}\text { View of the external } \\
\text { environment }\end{array}$ & $\begin{array}{l}\text { Objectively, comes from rational } \\
\text { objectives, opportunities, resources, } \\
\text { and environment limitations }\end{array}$ \\
\hline $\begin{array}{l}\text { The imposition of representations } \\
\text { of the environment requires an } \\
\text { explanation of any changes } \\
\text { (excuses, guessing) }\end{array}$ & $\begin{array}{l}\text { Attitudes towards } \\
\text { changes in the external } \\
\text { environment }\end{array}$ & $\begin{array}{l}\text { Flexibility in understanding the } \\
\text { «life cycle» environment, causes of } \\
\text { changes }\end{array}$ \\
\hline Not required & $\begin{array}{l}\text { Delegation of } \\
\text { functions }\end{array}$ & $\begin{array}{l}\text { Delegation is one of the important } \\
\text { functions and conditions for } \\
\text { achieving strategic goals }\end{array}$ \\
\hline $\begin{array}{l}\text { Actual sentence: "In the struggle } \\
\text { all means are good". }\end{array}$ & $\begin{array}{c}\text { The choice of } \\
\text { management tools }\end{array}$ & Different tools \\
\hline $\begin{array}{l}\text { Attitude as a means of obtaining } \\
\text { benefits. In the development of the } \\
\text { resource issue is not }\end{array}$ & $\begin{array}{l}\text { Related to human } \\
\text { resource }\end{array}$ & $\begin{array}{l}\text { Development people in accordance } \\
\text { with the analysis of existing } \\
\text { competencies }\end{array}$ \\
\hline Not required & Attitude to feedback & $\begin{array}{l}\text { Feedback is needed as the alarm } \\
\text { system on the destructive aspects in } \\
\text { the achievement of strategic goals }\end{array}$ \\
\hline Not required & $\begin{array}{c}\text { Requirements for the } \\
\text { subject }\end{array}$ & Requires self-organization Manager \\
\hline
\end{tabular}

\section{Conclusions}

The formation of a competence approach in the organization is similar to the search for a philosopher's stone. Scientific and methodical literature devoted to the subject under consideration is full of numerous methods. These methods are mainly declarative (simulative from J. Baudrillard), a formalized character. At their core, they are divorced from the object of managerial influence: from the employees of the organization. They were burden with complex terminology (competencies, grading, etc.). In the United States in competence-based pay great attention to the analysis of the description tasks 
(competence exists as a workplace). Description of tasks can was call proto-elements of competencee. Especially hard, particularly painstaking work was conduct by scientists in the direction of a unified, unambiguous interpretation of terms and concepts in the methods used. The seriousness of the plans confirms the fact that even reward systems were patent in the US. These systems were recognize as unique developments that allow the effective management of the company. In Russia at least, such a systems was impose to them. These systems were recognize as a commercial secret. However, they did not always meet the requirements of modern management. Examples of qualitative methods in the context of a competence approach can be those based on a factorial approach. Especially popular among them among management managers and researchers was the method of E.N. Hey (grading) [5] In the Soviet Union, scientists developed a similar project. They singled out the basic principles for assessing the quality and complexity of the work of experts (for determining the categories of qualifications and for differentiating salaries). Developed these recommendations of the Institute of Labor (on behalf of the USSR State Committee for Labor and Social Affairs). [4]. The foreign design of management functions and the results of Soviet researchers are very similar. Unfortunately, many achievements of the world and domestic science are lost in endless reforms. Theories and technologies that could help people form and develop interpersonal relationships are lost. These are theories and technologies of command formation and development of the collective. A look at the described problems through the concept of binary concept "simulation - dissimulation", "monosubjective - intersubjective", "focused - defocused", helps us to understand the true mechanisms of what is happening in modern management of aerospace objects [12].

\section{References}

1. J. Baudrillard. Simulyakri i simulyatsiya [In Russian] (Tula: Tulskiy poligrafist, 2013)

2. V. Demyanenko. Osobennosti upravleniya izmeneniyami v Rossii [In Russian] (Moscow: Publishing solutions, 2016)

3. I.V. Gorelova Kompetentnostnyy podkhod $k$ upravleniyu v Rossii: modelirovaniye ili dissimilyatsiya. [In Russian] (Belgorod: BSI, 2017)

4. Rekomendatsii po otsenke slozhnosti $i$ kachestva raboty spetsialistov [In Russian] (Moscow: Economics, 1989)

5. R. Henderson. Compensation management in a knowledge-based world (Upper Saddle River: Pearson Prentice Hall, 2006)

6. V.S. Katkalo. Evolyutsiya teorii strategicheskogo upravleniya [In Russian]. Author's abstract diss. of the doctor of economic sciences. - St.Petersburg (2007)

7. Y. S. Kostrova. Genezis ponyatiy «kompetenstiya» i «kompetentnost'» [In Russian]. Young scientist 12(2), 102 (2011)

8. А. F. Mоsкоvzev (ed.). Upravleniye razvitiyem strategicheskogo potentsiala regiona [In Russian] (Volgograd: VSTU, 2015)

9. G. Mintzberg, B. Ahlstrand, D. Lampel. Strategy safari: A guided tour through the wilds of strategic management (London: The Free Press, 1998)

10. A. Ovchinnikov. O klassifikatsii kompetentsii [In Russian]. Organizational psychology 4(4), 145 (2014)

11. V. A. Zhartun. Kosmicheskaya katastrofa [In Russian]. Sulakshin Center, 14 January, URL http://rusrand.ru/analytics/kosmicheskie-avarii (accessed: 18.01.2018) (2018)

12. V. A. Vittikh. Evolution of Ideas on Management Processes in the Society: From Cybernetics to Evergetics. Group Decision and Negotiation 24, 825 (2015) 